\title{
NEW LOCALITY \\ OF OROBANCHE COERULESCENS STEPHAN EX WILLD. (OROBANCHACEAE) AT THE NW LIMIT OF ITS GEOGRAPHICAL RANGE
}

\author{
RENATA PIWOWARCZYK, AlOJZY PRZEMYSKI \\ Department of Botany, Institute of Biology, \\ Jan Kochanowski University in Kielce \\ Świętokrzyska 15, 25-406 Kielce, Poland \\ e-mail: renka76@wp.pl
}

(Received: March 31, 2009. Accepted: August 13, 2009)

\begin{abstract}
A new locality of Orobanche coerulescens Stephan ex Willd. in the Wyżyna Małopolska upland (Garb Pińczowski hummock) in central Poland is presented. Over 290 specimens were recorded in a xerothermic grassland of the class Festuco-Brometea comprising species of the class Koelerio glaucae-Corynephoretea canescentis on alkaline, sandy soil. $O$. coerulescens is extinct at the majority of its localities in Poland and only two localities are known at present.
\end{abstract}

KEY WORDS: Orobanche coerulescens, Orobanchaceae, distribution, Wyżyna Małopolska upland, Garb Pińczowski hummock, Poland.

\section{INTRODUCTION}

Orobanche coerulescens Stephan ex Willd. (O. ammophila C. A. Mey), the bluish broomrape, is one of the rarest representatives of the family Orobanchaceae in Poland. It is red-listed as a critically endangered species (E) in Poland (Zarzycki and Szeląg 2006) and as an extinct species (Ex) in Western Pomerania (Żukowski and Jackowiak 1995). The taxon had been thought to be extinct until 2002 (Mądalski 1967; Zając and Zając 2001; Mirek et al. 2002). A new locality of the species, the only one in Poland until now, was published by Ciosek in 2002. The Polish species of Orobanche, including $O$. coerulescens, are strictly protected (Regulation of the Minister of Environment of 24th July 2004).

$O$. coerulescens belongs to the sect. Osproleon Wallr. (Orobanche L.) subsect. Inflatae Beck, grex Coerulescentes Beck (Beck 1890). A number of its forms have been described based mainly on the corolla length; f. occidentalis (G. Beck Monogr. Bot. 1890) is considered to be one of the most common forms in central Europe. Plants with white-yellow flowers which have been recognized as $\mathrm{f}$. korshinskyi Novopokr. or var. albiflora O. Kuntze have been reported from Japan as well as from Europe, Mongolia and Russia (Beck 1930; Zhiyun and Tzvelev 1998).

$O$. coerulescens is quite easy to distinguish from related species because of the characteristic thick stem, especially near the inflorescence, and numerous tiny, geniculately bent pale blue flowers. The entire plant, the stem in parti- cular, is heavily hairy and looks as if covered with mould when dry (Fig. 1).

\section{METHODS}

Field studies were carried out in the flowering period of Orobanche coerulescens from June until the end of July in 2007. The distribution of its localities was mapped using the ATPOL grid based on cartogram units $10 \times 10 \mathrm{~km}(\mathrm{Za}-$ jąc 1978).

The nomenclature of the vascular plant species listed in the phytosociological table follows Mirek et al. (2002) and the nomenclature of syntaxa is used after Matuszkiewicz (2006)

Herbarium specimens are deposited in the Herbarium of the Department of Botany, Jan Kochanowski University, Kielce (KTC).

\section{GENERAL DISTRIBUTION}

Orobanche coerulescens represents the Euro-Asian type of distribution (Rothmaler et al. 2002). It has been reported from: south-eastern Bavaria, northern Lithuania, Austria, the Czech Republic, Slovakia, Hungary, Poland, Belarus, Moldavia, the Russian Federation (European part), Ukraine, Bulgaria, Yugoslavia, Romania, the Caucasus, Ciscaucasia, Dagestan, Siberia, former Soviet Middle Asia: Kaza- 


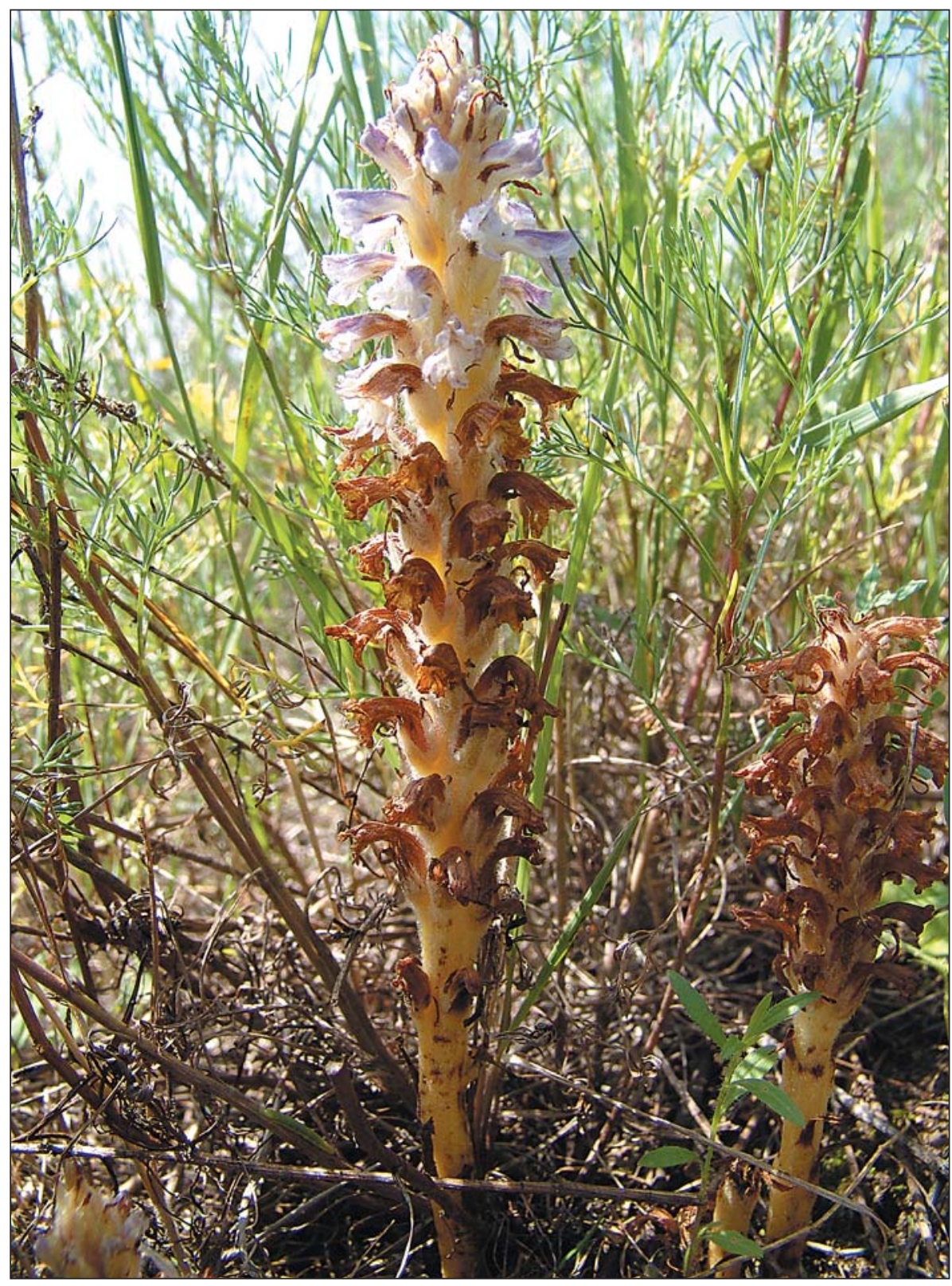

Fig. 1. Orobanche coerulescens Stephan ex Willd. on the Garb Pińczowski hummock (fot. R. Piwowarczyk, 25.06.2007). khstan, Turkmenistan, Kyrgyzstan, former Soviet Far East: Amur, Khabarovsk, Primorye; Mongolia, China, Eastern Asia: Japan, Korea, Taiwan; Indian Subcontinent: Nepal. Its northernmost sites in Europe are located in eastern Russia and Perm. It occurs in the centre of its range in desert and steppe areas as well as on sandy or rocky Asian coasts, especially in Central and East Asia, for instance Turkmenistan, Mongolia, China or Siberia (Beck 1890, 1930; Novopokrovskij 1958; Zoku 1965; Popov and Busik 1966; Chater et al. 1972; Meusel et al. 1978; Malyschev and Peschkova 1979; Tzvelev 1981; Uhlich et al. 1995; Kreutz 1995; Zhiyun and Tzvelev 1998; Zázvorka 2000). The species probably does not occur in the Mediterranean countries and south of the Danube. It has been erroneously reported from Italy (Pignatti 1982). The species is recognized as extinct at the majority of its localities at the western limit of its distribution (Kreutz 1995). Its populations are very scarce in central Europe; for instance, they comprise only a few specimens, sporadically up to 30 specimens, in the Czech Republic. They also occur at irregular, often long-term intervals (Zázvorka 2000; Holub and Zázvorka 1999). In Ger- many, it probably occurs only sporadically in Bavaria at present (Uhlich, Rätzel 2009 verb. inf.).

\section{DISTRIBUTION IN POLAND}

In Poland, the bluish broomrape has been reported from 10 localities in Pomerania currently considered to be extinct (Żukowski and Jackowiak 1995; Zając and Zając 2001). One locality has also been reported by Mądalski (1967) from Mt Krzyżowa near Olsztyn (Wyżyna Krakowsko-Częstochowska upland); the lack of herbarium specimens, however, makes its identification impossible. The present authors inspected the station in 2007 but no records were found. Fijałkowski (1994) also lists the species from the Lublin area; he does not, however, specify the exact location and no herbarium specimens are available. The Bohukały village near Terespol in the Podlaski Przełom Bugu gorge was the only current locality in Poland (Ciosek 2002) (Fig. 2). 




Fig. 2. Distribution of Orobanche coerulescens Stephan ex Willd. in Poland (in ATPOL grid $10 \times 10 \mathrm{~km}) ;[\mathbf{\Delta}]-$ new locality, [•] - locality given in literature, +- extinct locality.

\section{BIOLOGY AND HABITAT PREFERENCES}

Species of the genus Artemisia are mostly reported as host plants of $O$. coerulescens: A. campestris, A. capillaris, A. commutata, A. dracunculus, A. frigida, A. glauca, A. inodora, A. latifolia, A. marschalliana as well as Achillea millefolium, Lotus corniculatus, Medicago falcata (Beck 1890, 1930; Uhlich et al. 1995). Beck (1890, 1930) considers the latter three as incorrect. However, the species is mostly reported as a parasite of Artemisia campestris in central Europe, including Poland (Abromeit et al. 1898; Kreutz 1995; Uhlich et al. 1995; Zázvorka 2000; Ciosek 2002).

Orobanche coerulescens usually flowers from June until July, depending on the geographical position (Kreutz 1995).

It occurs in China at altitudes ranging from 900 to 4000 m (Zhiyun and Tzvelev 1998).

The data on phytocenotic amplitude of $O$. coerulescens are insufficient. In Europe, the species has been recorded mainly in the communities of the Festucion rupicolae association (Soó 1968) and of the orders Festucetalia valesiacae (Oberdorfer 1990; Rothmaler et al. 2002) and Festucion valesiacae (Potentillo arenariae-Festucenion pallentis) (Zázvorka 2000). In Bohukały near Terespol, the bluish broomrape grows in a xerothermic grassland of the class Festuco-Brometea, which is formed on former wastelands and cultivated fields (Ciosek 2002).

In Europe, the bluish broomrape grows in dry and semidry meadows, steppes, xerothermic grasslands, cultivated fields and xerothermic shrubs. It colonises warm alkaline and sandy soils, often rendzinas, based on the dolomite, chalk, limestone and basalt substructure (Kreutz 1995; Uhlich et al. 1995; Zázvorka 2000). In Asia, it prefers steppes, rocky or grassy slopes, grasslands, cultivated fields, desert areas, sandy hillsides, areas along rivers and near seashores (Zoku 1965; Tolmaczev 1974; Charkevicz 1996; Zhiyun and Tzvelev 1998; Sató 2004); it is reported less frequently from dry pinewoods and mixed woods (Malyschev and Peschkova 1979; Krasnoborov 1984).

The entire plant is used medicinally to invigorate the kidneys and strengthen yang, relax the bowels and strengthen the bones and muscles (Zhiyun and Tzvelev 1998).

\section{RESULTS}

\section{New locality}

A new locality of Orobanche coerulescens was found in the Wyżyna Małopolska upland within the Garb Pińczowski hummock between Pińczów and Pasturka during floristic studies in June 2007 (Fig. 3). The species grows in an old fallow between a cultivated field and a xerothermic grassland in a low-lying area at the foot of a chalky slope in the Garb Pińczowski hills. Species of the class FestucoBrometea dominate in the community (order Festucetalia valesiacae) which also comprises a number of species belonging to the class Koelerio glaucae-Corynephoretea canescentis. The hillside is slightly sloping towards the north and calcareous sands are present in the subsoil. The locality borders with xerothermic grasslands in the north and north-west and with fallows and cultivated fields in the 


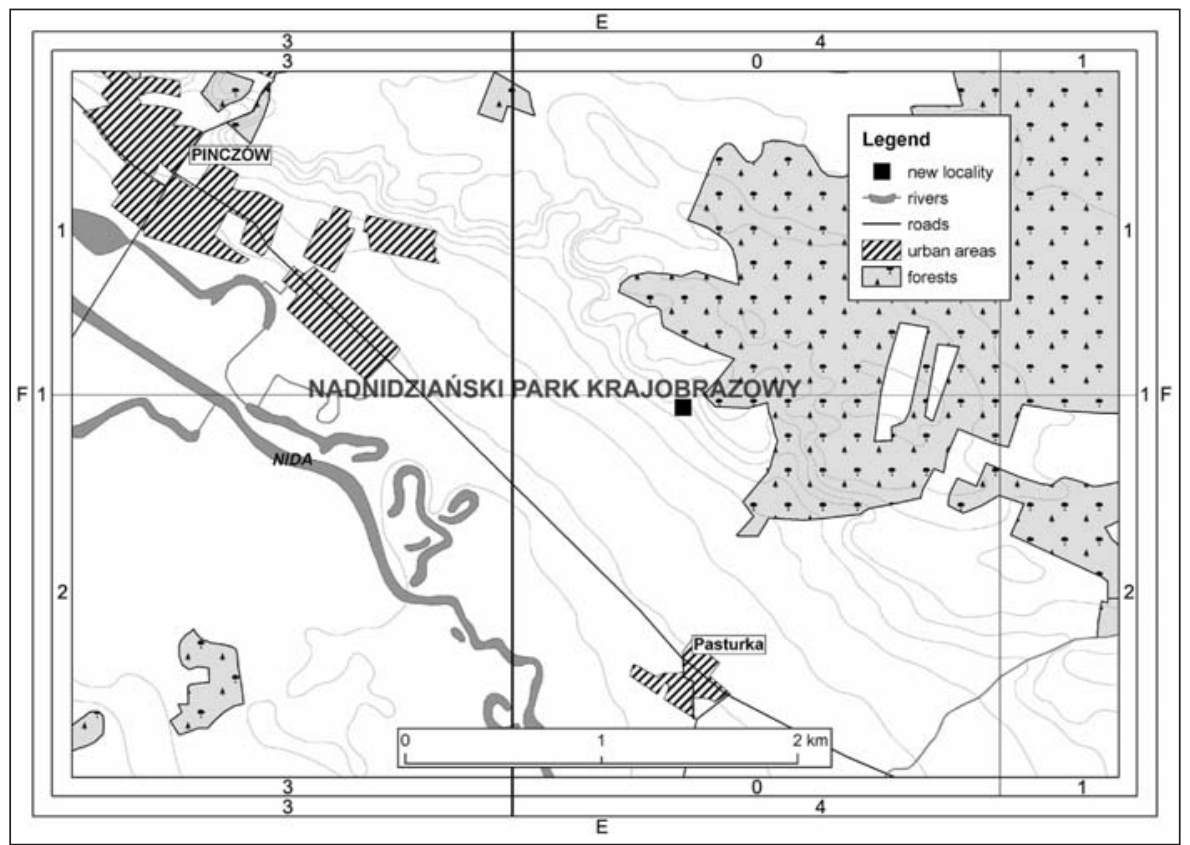

Fig. 3. New locality of Orobanche coerulescens Stephan ex Willd. on the Garb Pińczowski hummock. south and south-east. A total of 290 specimens which parasitizes only Artemisia campestris were observed in an area of $1500 \mathrm{~m}^{2}$. The species rarely occurs individually; it usually grows in clumps of several to even over 20 specimens.

The floristic composition of the community is given in a relevé below.

Relevé 1. Xerothermic grassland on the edge of the foot of the Garb Pińczowski slope and a fallow land and a cultivated field between the „Grodzisko" housing estate in Pińczów and the Pasturka village. Geogr. coord. 50³0'36' $\mathrm{N} / 20^{\circ} 33^{\prime} 39^{\prime}$ 'E; date: 25.06.2007; patch area $100 \mathrm{~m}^{2}$; altitude $227 \mathrm{~m}$; exposure $\mathrm{S}$; inclination $3^{\circ}$; ATPOL cartogram grid 2,5×2,5 km (Zając 1978): EF1420. The cover of the herb layer ' $\mathrm{C}$ ': $90 \%$.

Orobanche coerulescens + , Trifolium arvense 4, Artemisia campestris 3, Arenaria serpyllifolia 2, Lolium perenne 2, Elymus repens 2, Silene otites 1, Verbascum lychnitis 1, Medicago minima 1, Plantago indica 1, Sedum maximum ,+ Lappula squamosa + , Orobanche arenaria,$+ O$. picridis + , Androsace septentrionalis + , Berteroa incana,+ Medicago lupulina,+ M. sativa + , Apera spica-venti + , Dianthus cartusianorum + , Raphanus raphanistrum + , Sedum acre + , Lathyrus tuberosus +, Vicia hirsuta + , V. tetrasperma + , Conyza canadensis + , Erigeron acer + , Matricaria maritima subsp. inodora + , Coronilla varia + , Anchusa officinalis + , Anthemis tinctoria + , Veronica arvensis + , Veronica spicata + , Veronica verna + , Polygonum convolvulus + , Asparagus officinalis + , Bromus tectorum + , Phleum phleoides + , Knautia arvensis + , Centaurea stoebe + , Tragopogon major + , Linum hirsutum + , Descurainia sophia + , Campanula sibirica + , Senecio jacobaea,+ Pastinaca sativa,$+ \mathrm{Li}$ naria vulgaris + , Artemisia vulgaris + , Daucus carota + , Picris hieracioides + , Taraxacum officinale s.1. +, Echium vulgare,+ Melandrium album + , Origanum vulgare,$+ P a$ paver rhoeas + , Viola arvensis + .

\section{CONCLUSIONS}

The bluish broomrape grows on sands in a thermophilous grassland with a high number of species of the classes Fe-
stuco-Brometea and Koelerio glaucae-Corynephoretea canescentis, the Koelerion glaucae alliance, and an admixture of meadow, ruderal and segetal species at the present locality. The species parasitizes only Artemisia campestris. The flowering optimum was observed in the first half of June.

At present, it is the second confirmed and most numerous locality (290 specimens) in Poland. Only one clump with 19 shoots was recorded in Bohukały (Ciosek 2002). The new locality is situated within the general range limit of the species. It is probably one of the most numerous populations of the species at the western and north-western range limit.

\section{THREATS AND PROTECTION METHODS}

The future occurrence of Orobanche coerulescens populations at the locality depends mainly on the continuation of the current extensive agricultural practice: combined periodic shallow ploughing and mowing. If mowing only is performed, vegetation could transform into a xerothermic grassland, the cover degree of the herb layer will increase, annual and biennial species will be driven out by perennial plants and secondary succession of shrubs and trees will begin. The bluish broomrape stops occurring in such conditions. Intensification of cultivation methods, mostly the application of chemical agents (herbicides), also constitutes a threat. Numerous specimens probably paralysed following herbicide treatment were found during inspection in 2008.

The station is located within the Nida Landscape Park, where a sanctuary has been planned as part of the Natura 2000 ecological network. It may also be recommended to introduce other forms of nature conservation.

The new locality of $O$. coerulescens in Poland should be recognized as a relic and critically endangered site where special protection measures must be used. It should be included in an environmental monitoring programme and active protection treatment should be locally applied, especially as other rare species of the Orobanchaceae family, e.g. Orobanche arenaria, O. elatior, O. picridis, O. lutea, also occur in the area. 


\section{ACKNOWLEDGEMENTS}

The authors thank Holger Uhlich and Stephan Rätzel for providing the information on the current occurrence of the species in Germany and Prof. Adam Zając for helpful comments on the manuscript.

This work was supported by the Polish State Committee for Scientific Research (KBN grant no. 3577/B/P01/2007/ $33)$.

\section{LITERATURE CITED}

ABROMEIT J., NEUHOFF W., STEFFEN H. 1898. Flora von Ost- und Westpreussen: 1/1-25: 1-402. In Kommision bei R. Friedländer \& Sohn, Berlin.

BECK VON MANNAGETTA G.R. 1890. Monographie der Gattung Orobanche. Biblioth. Bot. 19, Cassel.

BECK VON MANNAGETTA G.R. 1930. Orobanchaceae L. In: A. Engler (eds), Das Pflanzenreich IV. (261), Leipzig.

CHARKEVICZ S.S. (ed.) 1996. Plantae vasculares orientis extremi sovietici 8. Saint Petersburg, Nauka. (in Russian)

CHATER A.O., WEBB D.A. 1972. Orobanche L. In: T.G. Tutin, V.H. Heywood, N.A. Burges, D.M. Moore, D.H. Valentine, S.M. Walters, D.A. Webb. Flora Europaea 3: 286-293, Cambrige.

CIOSEK M.T. 2002. Stanowisko zarazy błękitnawej Orobanche coerulescens Stephan ex Willd. w Bohukałach koło Terespola (Podlaski Przełom Bugu). Acta Scientiarum Polonorum - Biologia 1(1-2): 5-7. (in Polish with English summary)

FIJAŁKOWSKI D. 1994. Flora naczyniowa Lubelszczyzny. Lubel. Tow. Nauk Przyr. T. 1 and 2. Lublin. (in Polish)

HOLUB J., ZÁZVORKA J. 1999. Orobanche coerulescens Stephan. in Willd. In: J. Čeřovský, V. Feráková, J. Holub, S. Maglocký, F. Procházka (eds), Červená kniha ohrozených a vzácných druhov rastlin a živočichov SR a ČR. 5. Vyššie rastliny. Priroda a. s., Bratislava. (in Slovak)

KRASNOBOROV I.M. (ed.) 1984. Opredelitel rastienij Tuwinskoj ACCP. Akademia Nauk CCCR, Novosibirsk.

KREUTZ C.A.J. 1995. Orobanche. The European broomrape species. Central and northern Europe, Limburg.

MALYSCHEV L.J., PESCHKOVA G.A. 1979. Flora Sibiriae Centralis t. 2. Academia Scientarum URSS, Nauka, Divisio Sibiria, Novosibirsk.

MATUSZKIEWICZ W. 2006. Przewodnik do oznaczania zbiorowisk roślinnych Polski. Vademecum Geobotanicum. PWN Warszawa. (in Polish)

MĄDALSKI J. 1967. Orobanchaceae. In: K. Browicz et al. (eds), Flora Polska. Tom XI, 25-53; Warszawa, Kraków. (in Polish)

MEUSEL H., JÄGER E., RAUSCHERT S., WEINERT E. 1978. Vergleichende chorologie der Zentraleuropäischen flora. Bd II. G. Fischer Verl. Jena.

MIREK Z., PIĘKOŚ-MIREK H., ZAJĄC A., ZAJĄC M. 2002. Flowering plants and pteridophytes of Poland - a checklist. In:
Z. Mirek (ed.), Biodiversity of Poland. Instytut Botaniki im. W. Szafera, Polska Akademia Nauk, Kraków, 1: 1-442.

NOVOPOKROVSKIJ I.V., TZVELEV N.N. 1958. Orobanchaceae. In: B.K. Schischkin (ed.), Flora SSSR 23, pp. 19-117. Academia Scientarum URSS, Moskwa-Leningrad.

OBERDORFER E. 1990. Pflanzensoziologische Exkursionflora. Verlag Euglen Ulmer.-Stuttgart.

PIGNATTI S. 1982. Flora d'Italia, Orobanchaceae, p. 606-616. Bologna. (in Italian)

POPOV M.G., BUSIK W.W. 1966. Konspekt flory poberezij Oziera Bajkal. Akademia Nauk CCCR. Moskwa-Leningrad.

ROTHMALER W., JÄGER E.J., WERNER K. 2002. Exkursionsflora von Deutschland - Kritischer Band 4. Berlin.

SATÓ M. 2004. The first record of Orobanche coerulescens from Rishiri Island (northern Hokkaido). Rishiri Studies 23: 3,5. (in Japanese with English summary).

SOÓ R. 1968. A Magyar flora es vegetacio rendszertani növenyföldrajzi. Kezikönyre 3. Budapest. (in Hungarian)

TOLMACZEV A.J. 1974. Opredelitel wyssych rastienij Jakuty. Akademia Nauk CCCR, Novosibirsk.

TZVELEV N.N. 1981. Orobanchaceae. In: A.A. Fedorov (ed.), Flora evropeyskoy chastii SSSR 5: 317-335. Izdatel'stvo Nauka, Leningrad. (in Russian)

UHLICH H., PUSCH J., BARTHEL K.J. 1995. Die Sommerwurzarten Europa: Gattung Orobanche. Westarp-Wiss., Magdeburg.

ZAJĄC A. 1978. Założenia metodyczne "Atlasu rozmieszczenia roślin naczyniowych w Polsce". Wiad. Bot. 22(3): 145-155. (in Polish)

ZAJĄC A., ZAJĄC M. (eds) 2001. Atlas rozmieszczenia roślin naczyniowych w Polsce. Nakładem Pracowni Chorologii Komputerowej Instytutu Botaniki Uniwersytetu Jagiellońskiego, Kraków. (in Polish with English summary)

ZARZYCKI K., SZELĄG Z. 2006. Red list of the vascular plants in Poland. In: Z. Mirek, K. Zarzycki, W. Wojewoda, Z. Szeląg (eds), Red list of plants and fungi in Poland. pp. 9-20. W. Szafer Institute of Botany, Polish Academy of Sciences, Kraków.

ZÁZVORKA J. 2000. Orobanchaceae - zarazovite. In: B. Slavik (ed.), Kvetena Česke Republiky 6, Academia Praha. (in Czech)

ZHIYUN J., TZVELEV N.N. 1998. Orobanchaceae. In: W. Zheng-yi, P.H. Raven (ed.), Flora of China Vol. 18, Beijing: Science Press \& St. Louis: Missouri Botanical Garden, p. 229-243 .

ZOKU H.U. 1965. Orobanche L. In: J. Ohwi (ed.), Flora of Japan. National Science Museum Tokyo, Japan; Smithsonian Institution Washington D. C.

ŻUKOWSKI W., JACKOWIAK B. 1995. Lista roślin naczyniowych ginących i zagrożonych na Pomorzu Zachodnim i w Wielkopolsce. In: W. Żukowski, B. Jackowiak (eds), Ginące i zagrożone rośliny naczyniowe Pomorza Zachodniego i Wielkopolski. Publications of the Departament of Plant Taxonomy of Adam Mickiewicz University in Poznań 3. Poznań. (in Polish with English summary) 